\title{
Corrosion and Wear Behaviors of Boronized AISI 316L Stainless Steel
}

\author{
Yusuf Kayali $^{1, *}$, Aysel Büyüksağişs ${ }^{2}$, and Yılmaz Yalçin ${ }^{1}$ \\ ${ }^{1}$ Afyon Kocatepe University, Technology Faculty, Department of Metallurgical and Materials \\ Engineering, Afyon 03200, Turkey \\ ${ }^{2}$ Afyon Kocatepe University, Science and Art Faculty, Afyon 03200, Turkey \\ (received date: 7 February 2012 / accepted date: 26 November 2012)
}

\begin{abstract}
In this study, the effects of a boronizing treatment on the corrosion and wear behaviors of AISI 316L austenitic stainless steel (AISI 316L) were examined. The corrosion behavior of the boronized samples was studied via electrochemical methods in a simulation body fluid (SBF) and the wear behavior was examined using the ball-on-disk wear method. It was observed that the boride layer that formed on the AISI $316 \mathrm{~L}$ surface had a flat and smooth morphology. Furthermore, X-ray diffraction analyses show that the boride layer contained $\mathrm{FeB}, \mathrm{Fe}_{2} \mathrm{~B}, \mathrm{CrB}, \mathrm{Cr}_{2} \mathrm{~B}, \mathrm{NiB}$, and $\mathrm{Ni}_{2} \mathrm{~B}$ phases. Boride layer thickness increased with an increasing boronizing temperature and time. The boronizing treatment also increased the surface hardness of the AISI 316L. Although there was no positive effect of the coating on the corrosion resistance in the SBF medium. Furthermore, a decrease in the friction coefficient was recorded for the boronized AISI 316L. As the boronizing temperature increased, the wear rate decreased in both dry and wet mediums. As a result, the boronizing treatment contributed positively to the wear resistance by increasing the surface hardness and by decreasing the friction coefficient of the AISI 316L.
\end{abstract}

Key words: AISI 316L stainless steel, surface modification, corrosion, wear, scanning electron microscopy (SEM)

\section{INTRODUCTION}

AISI 316L stainless steel has a wide variety of uses in various industry sectors including chemistry, petrochemistry, paper industries, and nuclear engineering due to its high corrosion resistance at high temperatures. Furthermore, due to its biocompatibility and high corrosion resistance, it has been used in medicine as an implant material [1-4]. Despite such superior properties, its uses have been limited because it has a low hardness and weak wear performance [2,4]. In order to remove these limitations, many studies have been conducted with the aim of improving the surface hardness of AISI 316L stainless steel as well as its corrosion and wear behaviors. These studies include Ti coating via the physical vapor deposition (PVD) method [2,5-8], diamond-like carbon (DLC) coating $[9,10], \mathrm{Cr}_{2} \mathrm{~B}$ spray-coating [11], hard $\mathrm{Cr}$ coating [12], sol-gel [6], plasma nitriding [1,3,4,13], plasma nitrocarburizing [14], and thin, hard coatings using several plasmabased surface technologies [15].

Coatings are normally used to improve the corrosion and wear properties of metals. There are numerous coating methods, e.g. galvanizing, electrode position, electroless plating, metal spraying, physical vapor deposition (PVD), chemical

*Corresponding author: ykayali@aku.edu.tr

CKIM and Springer, Published 10 September 2013 vapor deposition (CVD), etc., that provide coatings that protect metals in aggressive mediums [2,16,17]. Some of these coating methods are very expensive and some provide a surface hardness of up to $900 \mathrm{Hv}$. However, the boronizing treatment is easy to apply, cheaper, and offers superior properties. Boronizing is a thermo-chemical diffusion process in which boron is diffused into steel under high temperatures $[18,19]$. It offers superior properties including a surface hardness of 1400-3000 Hv. The boronized reaction layer maintains its hardness at high temperatures $\left(550-600{ }^{\circ} \mathrm{C}\right)$ and has a very low friction coefficient and corrosion resistance against acids, bases, and high temperature oxidations [18,20-27].

It is well known that AISI 316L stainless steel is used as an implant material due to its high corrosion resistance and biocompatibility. Despite its excellent properties, the wear resistance of AISI 316L stainless steel is very low due to its insufficient surface hardness; this also limits its applications $[2,4,12,14,15]$. Wear resistance is important for moving implant materials such as joints in the body; therefore, the wear resistance of boronized AISI 316L stainless steel is significant in the SBF medium, as well as its corrosion and biocompatibility.

Many studies on the wear of the boride layer and the boriding of stainless steel have been undertaken. However, there have not yet been studies that investigate the behaviors of boronized implant steels in vivo or in vitro mediums [7]. Therefore, the primary objective of this study is to determine the 
corrosion and wear behaviors of boronized and non-boronized AISI 316L stainless steel in the SBF medium.

\section{EXPERIMENTAL PROCEDURES}

\subsection{Boronized layer and its characterization}

In this study, AISI 316L stainless steel was used and its chemical composition is given in Table 1. Cylindrical specimens with a diameter of $15 \mathrm{~mm}$ and a length of $10 \mathrm{~mm}$ were used in the corrosion tests and cylindrical specimens with a diameter of $20 \mathrm{~mm}$ and a length of $6 \mathrm{~mm}$ were used in the wear tests.

The boronizing was performed in a solid medium using Ekabor 2 powders that had a nominal chemical composition of $90 \% \mathrm{SiC}, 5 \% \mathrm{~B}_{4} \mathrm{C}$, and $5 \% \mathrm{KBF}_{4}$. The boronizing treatments were performed at $800{ }^{\circ} \mathrm{C}$ and $900{ }^{\circ} \mathrm{C}$ for $2 \mathrm{~h}$ and $6 \mathrm{~h}$, respectively.

The microstructures of the polished and etched cross-sections of the specimens were examined using scanning electron microscopy (SEM; Leo 1430VP, Carl Zeiss, Inc., Germany). The presence of borides formed in the coating layer was confirmed via X-ray diffraction (XRD-6000, Shimadzu, Japan) using $\mathrm{CuK} \alpha(\lambda=1,5406 \AA)$ radiation. The thicknesses of the boride layers were measured using a digital thickness measuring instrument attached to an optical microscope (Olympus BX-60, Olympus, Japan). The thickness values were the averages of at least ten measurements. The hardness of the boride layers was assessed via micro-Vickers indentations using a Vickers micro-hardness tester (Shimadzu HMV-2, Shimadzu, Japan) on polished cross-sections with a $50 \mathrm{~g}$ load.

\subsection{Corrosion tests}

The corrosion tests were carried out using Gamry Reference 600 Potentiostat/Galvanostat device (Gamry Instruments, USA) supported by the Echem Analyst Software (Gamry Instruments, USA). The samples, which were cleaned ultrasonically for $15 \mathrm{~min}$. at $30^{\circ} \mathrm{C}$ in acetone, ethyl alcohol, and double distilled water, were then dried in a drying oven at $40{ }^{\circ} \mathrm{C}$. The composition of the simulation body fluid (SBF) medium used in the tests is given in Table 2 . The potentiodynamic corrosion tests were carried out after holding the cleaned samples in the SBF medium for $1 \mathrm{~h}$ and $168 \mathrm{~h}$.

\subsection{Wear tests}

The boronized and non-boronized specimens were subjected to wear tests in dry and wet (i.e. SBF) mediums in a ball-on-disc system. The wear tests of the boronized AISI 316L stainless steels were performed with a Tribometer ballon-disk tester (CSM Instruments, Switzerland), using an 8
Table 2. Composition of the simulated body fluid (SBF) medium

\begin{tabular}{lc}
\hline Compound & Composition $\left(\mathrm{gL}^{-1}\right)$ \\
\hline $\mathrm{NaHCO}_{3}$ & 0.3528 \\
$\mathrm{MgCl}_{2}-6 \mathrm{H}_{2} \mathrm{O}$ & 0.304 \\
$\mathrm{CaCl}_{2}-2 \mathrm{H}_{2} \mathrm{O}$ & 0.367 \\
$\mathrm{~K}_{2} \mathrm{HPO}_{4}-3 \mathrm{H}_{2} \mathrm{O}$ & 0.228 \\
$\mathrm{Na}_{2} \mathrm{SO}_{4}$ & 0.071 \\
$\mathrm{NaCl}$ & 7.99 \\
$\mathrm{KCl}$ & 0.22 \\
$\mathrm{NaN}_{3}$ & 0.02 \\
\hline
\end{tabular}

mm-diameter WC-Co ball. The tests were conducted at an applied load of $5 \mathrm{~N}$ for $0.3 \mathrm{~m} / \mathrm{s}$ of sliding rate at room temperature (approximately $20^{\circ} \mathrm{C}$ ). The wear rates of the samples were obtained using following equation:

$$
W=\frac{2 \pi\left(R+\frac{L}{2}\right) \frac{r^{2}}{2}(\theta-\sin \theta)}{\text { Sliding Dis tan ce }},
$$

where $W$ is the wear rate $\left(\mathrm{mm}^{3} / \mathrm{Nm}\right), L$ is the wear track thickness $(\mathrm{mm}), R$ is the radius of the wear scar $(\mathrm{mm}), r$ is the radius of ball (mm), and $\theta=2$ arcsine $(L / 2 r)$ (radian).

The thickness of the wear track was measured using optical microscopy and the worn surfaces were examined via scanning electron microscopy (SEM).

\section{RESULTS AND DISCUSSION}

\subsection{Microstructure and characterization}

It can be seen in Fig. 1 that as a result of the metallographic examination of the boronized samples, the coating matrix interface morphology has a smooth and flat structure. The boride layer formed on the AISI 316L stainless steel has a flat, thin structure when compared with other boronized steels studied in references [28] to [32]. The high amount of alloying elements in the AISI 316L stainless steel slows the diffusion process $[28,29]$. As the amount of $\mathrm{Cr}$ in the steel increases, the boride layer on the steel becomes even thinner and the interface between the matrix and the boride layer becomes progressively flatter [28-32].

As seen in Fig. 2, the coating layer on the AISI 316L stainless steel consists of three zones. Zone 1 is the boride layer ( $\mathrm{FeB}, \mathrm{Fe}_{2} \mathrm{~B}, \mathrm{CrB}, \mathrm{Cr}_{2} \mathrm{~B}, \mathrm{NiB}$, and $\mathrm{Ni}_{2} \mathrm{~B}$ ). Zone 2 is the section under the boride layer; this zone consists of boron in a solid solution and has a lower hardness than the first boride layer. Zone 3 is the section of the steel that is not affected by the boronizing treatment $[19,29,31-33]$.

As the boronizing temperature and time increase, it can be

Table 1. Chemical composition of the test materials (wt\%)

\begin{tabular}{ccccccccccc}
\hline $\mathrm{C}$ & $\mathrm{Cr}$ & $\mathrm{Ni}$ & $\mathrm{Si}$ & $\mathrm{Mn}$ & $\mathrm{Mo}$ & $\mathrm{S}$ & $\mathrm{P}$ & $\mathrm{Cu}$ & $\mathrm{N}$ & $\mathrm{Ti}$ \\
\hline 0.02 & 16.89 & 10.62 & 0.39 & 1.50 & 2.11 & 0.03 & 0.033 & 0.34 & 0.054 & 0.008 \\
\hline
\end{tabular}




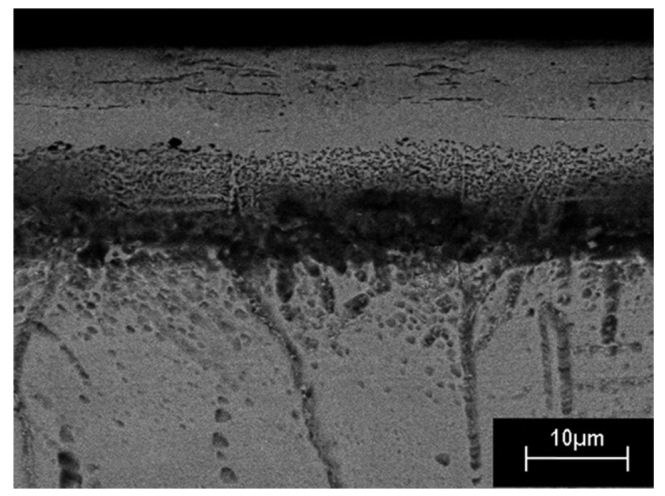

Fig. 1. SEM image of the AISI 316L stainless steel boronized at $900{ }^{\circ} \mathrm{C}$ for $6 \mathrm{~h}$ showing the boride layer and substrate metal.
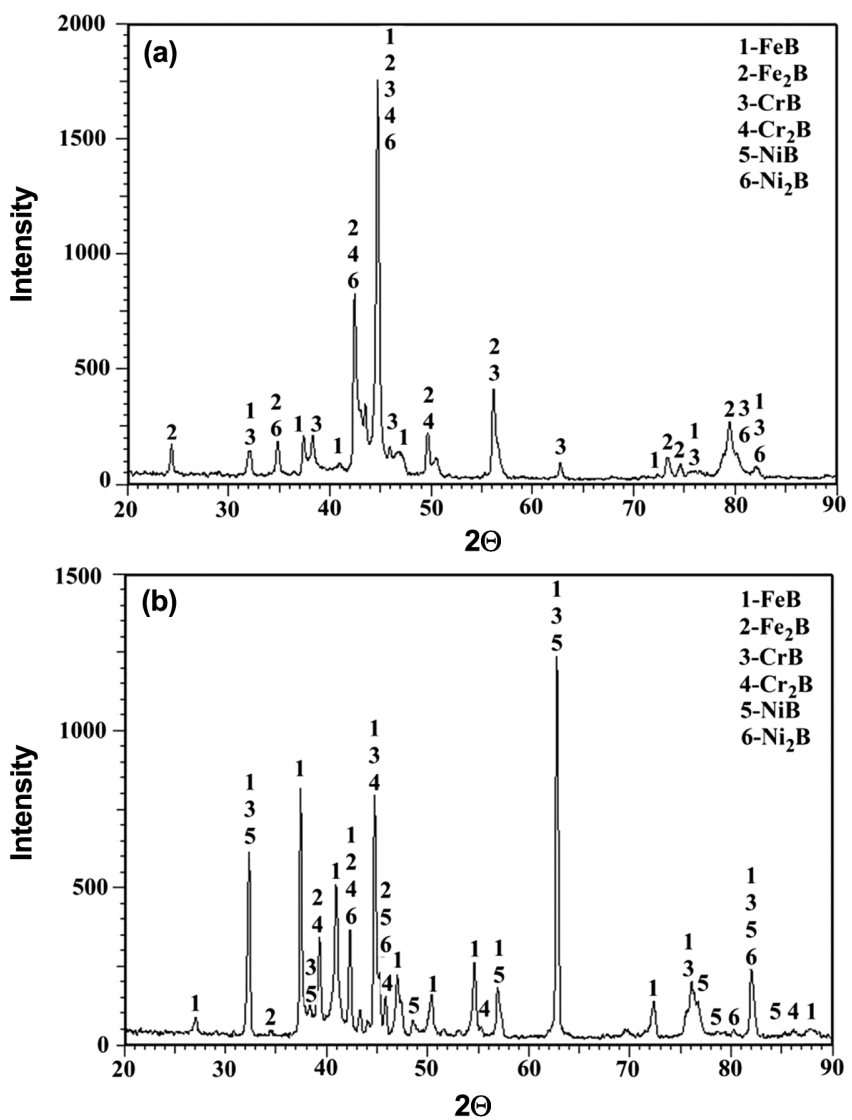

Fig. 2. XRD patterns observed from the surface of the AISI 316L stainless steel boronized at (a) $800{ }^{\circ} \mathrm{C}$ for $2 \mathrm{~h}$ and (b) $900{ }^{\circ} \mathrm{C}$ for $6 \mathrm{~h}$.

seen that $\mathrm{FeB}, \mathrm{CrB}$, and $\mathrm{NiB}$ phases become dominant and the intensities of the $\mathrm{Fe}_{2} \mathrm{~B}$ and $\mathrm{Cr}_{2} \mathrm{~B}$ phase peaks decreases (Fig. 2). The boride layer thicknesses of the AISI 316L stainless steels at different temperatures and times change between 2.3 and $25 \mu \mathrm{m}$. Along with an increase in the boronizing temperature and time, the thickness of the boride layer also increases $[29,32,33]$.

The hardness measurements were performed using a Knoop tip. The average values of the boronized samples were calcu- lated from the average of ten surface measurements. The hardness of the boride layer was between $1836 \mathrm{HK}_{0.05}$ and $2227 \mathrm{HK}_{0.05}$; however, the hardness of the base material was $334 \mathrm{HK}_{0.05}$. The increase in the surface hardness through the boronizing treatment has been provided previously in other studies $[34,35,37]$.

\subsection{Corrosion properties of the boride layer}

The corrosion characteristics of the boronized and nonboronized AISI 316L stainless steel obtained from the Tafel and linear polarization method in the SBF solution after $1 \mathrm{~h}$ and $168 \mathrm{~h}$ of holding time are given in Table 3 . As seen in Table 3 , the polarization current density $\left(i_{\text {corr }}\right)$ values of the boronized samples increased in the SBF solution after $1 \mathrm{~h}$ and $168 \mathrm{~h}$ of holding time. While the polarization current density values were $0.058-0.074 \mu \mathrm{A} / \mathrm{cm}^{2}$ for the uncoated condition, the polarization current density values in the range of $0.908-14.79 \mu \mathrm{A} / \mathrm{cm}^{2}$ measured for the boronized specimens changed according to the boronizing time and temperature. In both holding times for uncoated specimens, the anodic Tafel curve ( $\mathrm{\beta a}$ ) values demonstrated that the corrosion rate was anodic diffusion controlled and that the $E_{\text {corr }}$ values shifted toward more negative values and reached a peak in the $1 \mathrm{~h}$ holding time.

The oxide film on the surface of the $316 \mathrm{~L}$ stainless steel consists of two regions: the inner region that primarily consists of chromium oxide and the outer region that primarily consists of iron oxide and nickel oxide. The stoichiometry of the outer layer includes various iron oxides [46], and the AISI 316L stainless steel has high concentrations of alloy elements (Cr, Ni). In addition, as the amount of $\mathrm{Cr}$ and $\mathrm{Ni}$ matrix increased, the boride layer/matrix interface became flat instead of a columnar structure. Furthermore, due to the increased porosities in the coatings, the alloying elements of the boride layer replaced the iron atoms $[28,29,39,41]$. The $\mathrm{Cr}$ elements preferably diffused into the iron-boride layer during the boriding treatment. In contrast, the Ni was concentrated under the boride layer [18,19]. While this was caused by an increase of porosity in the boride layer, the mechanical properties of the coating were affected adversely $[18,39]$. In the SBF medium, the corrosion resistances of the boronized samples were quite weak; furthermore, the $\mathrm{Cl}$ ions, which form dissoluble complex salts (e.g. $\mathrm{CrCl}_{3}, \mathrm{FeCl}_{2}$, and $\mathrm{NiCl}_{2}$ ) with alloying elements under and in the boride layer, increased the corrosion rate due to the increase in the poro numbers. Therefore, the anticipated improvement in the corrosion resistance could not be achieved by the boronizing treatment due to the higher $i_{\text {corr }}$ and lower $R p$ values of the boronized AISI 316L stainless steel than the uncoated condition [4]. As the temperature increased, the metals and alloys suffered increasingly higher rates of oxidation [48]. The long-time exposure of 316 stainless steels to elevated temperatures is known to cause decomposition of the austenitic matrix result- 
Table 3. Corrosion characteristics of the boronized and non-boronized AISI 316L stainless steels in the SBF medium

\begin{tabular}{|c|c|c|c|c|c|c|c|}
\hline Conditions & $37^{\circ} \mathrm{C}$ in $\mathrm{SBF}$ & $\beta \mathrm{a}\left(\times 10^{-3}\right)(\mathrm{V} / \mathrm{dec})$ & $\beta \mathrm{c}\left(\times 10^{-3}\right)(\mathrm{V} / \mathrm{dec})$ & $\mathrm{E}_{\text {corr }}(\mathrm{mV})$ & $\mathrm{i}_{\text {corr }}\left(\mu \mathrm{A} / \mathrm{cm}^{-1}\right)$ & $\mathrm{Rp}(\mathrm{k})$ & Corrosion rate (mpy) \\
\hline \multicolumn{8}{|c|}{$1 \mathrm{~h}$} \\
\hline Non-boronized & Uncoated & $1 \times 10^{18}$ & 34.470 & -266 & 0.074 & 128.900 & 0.033 \\
\hline \multirow{4}{*}{ Boronized } & $800^{\circ} \mathrm{C} 2 \mathrm{~h}$ & 185 & 273 & -504 & 11.2 & 2.120 & 5.130 \\
\hline & $900{ }^{\circ} \mathrm{C} 2 \mathrm{~h}$ & 230.770 & 291.400 & -390 & 11.84 & 2.566 & 5.428 \\
\hline & $800^{\circ} \mathrm{C} 6 \mathrm{~h}$ & 310.900 & 308.100 & -508 & 13.73 & 2.352 & 6.301 \\
\hline & $900{ }^{\circ} \mathrm{C} 6 \mathrm{~h}$ & 178.100 & 268 & -574 & 14.79 & 1.654 & 6.772 \\
\hline \multicolumn{8}{|c|}{$168 \mathrm{~h}$} \\
\hline Non-boronized & Uncoated & $5 \times 10^{18}$ & 36.400 & -255 & 0.058 & 180.430 & 0.024 \\
\hline \multirow{4}{*}{ Boronized } & $900^{\circ} \mathrm{C} 2 \mathrm{~h}$ & 209.600 & 262.100 & -396 & 0.908 & 31 & 0.328 \\
\hline & $800{ }^{\circ} \mathrm{C} 6 \mathrm{~h}$ & 230.700 & 226.400 & -462 & 0.931 & 29.600 & 0.571 \\
\hline & $800^{\circ} \mathrm{C} 2 \mathrm{~h}$ & 376.180 & 151.530 & -413 & 1.324 & 21.660 & 0.607 \\
\hline & $900{ }^{\circ} \mathrm{C} 6 \mathrm{~h}$ & 286.800 & 692.300 & -386 & 6.392 & 7.594 & 2.942 \\
\hline
\end{tabular}
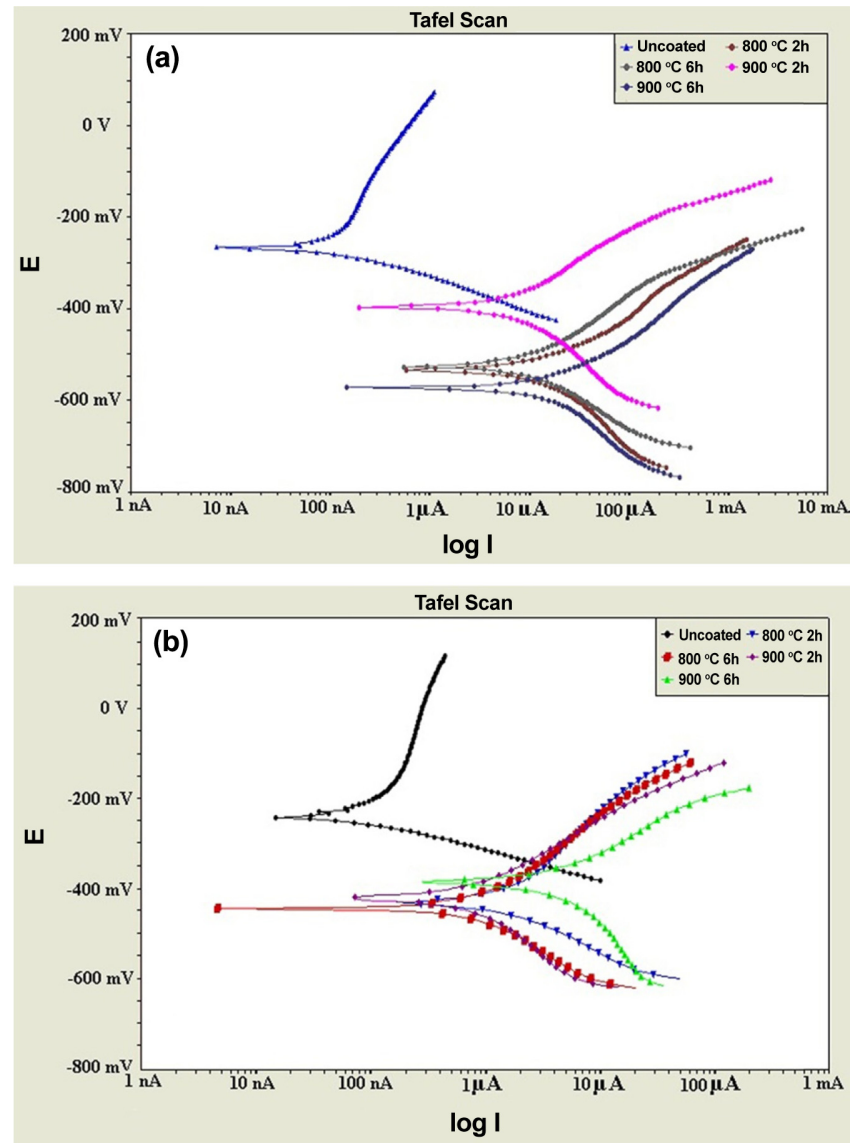

Fig. 3. Tafel curves of the boronized and non-boronized AISI 316L stainless steel in SBF solution for (a) $1 \mathrm{~h}$ and (b) $168 \mathrm{~h}$.

ing in the formation of several carbide and intermetallic phases [47].

The Tafel curves of the boronized and non-boronized AISI 316L stainless steel obtained using the Tafel polarization method after holding times of $1 \mathrm{~h}$ and $168 \mathrm{~h}$ in the SBF solution are given in Fig. 3. As seen in Fig. 3, the polarization current density values obtained for $1 \mathrm{~h}$ of holding time in the SBF medium were higher than those for $168 \mathrm{~h}$ of holding time. When the boronized samples were compared, the lowest corrosion rates were obtained for the samples boronized at 800 and $900{ }^{\circ} \mathrm{C}$ for $2 \mathrm{~h}$. It is also seen that the corrosion resistance increased with increases in the holding time in the medium. This also demonstrated that the oxides, which occur over time, cover the surface and decrease the anodic dissolution; therefore, the boride layer provides more effective protection with longer holding times.

Although Mo was detected via energy dispersive X-ray spectroscopy analysis (EDX) on the surface of the uncoated specimens after the corrosion experiments in the SBF medium, it could not be detected on the surface of the specimens boronized for $6 \mathrm{~h}$ at $900{ }^{\circ} \mathrm{C}$, which had the lowest corrosion resistance. This result might indicate that the Mo element positively affects the corrosion resistance (Fig. 4).

\subsection{Friction and wear properties of the boride layer}

In Fig. 5, the friction coefficient variations of the boronized and non-boronized AISI 316L stainless steel specimens that were tested for wear in dry and SBF mediums are presented according to the boronizing temperature and time. The lowest friction coefficient value was measured for the sample worn at $800^{\circ} \mathrm{C}$ for $6 \mathrm{~h}$ in the SBF medium, while the highest friction coefficient was measured for the uncoated AISI 316L stainless steel sample in the dry medium. While the friction coefficient of the uncoated samples was 0.72 in the dry medium, the friction coefficients at the end of the boronizing process varied between 0.523 and 0.579 . According to the literature, the friction coefficient of boronized steel samples can be as high as $0.65[34,35]$. Whereas in the SBF medium, while the friction coefficient of uncoated (nonboronized) samples was 0.330 , the friction coefficients at the end of the boronizing treatment varied between 0.086 and 0.269 . The friction coefficient values obtained in this study agree with the literature [35-37].

With an increase in the temperature and duration of the boronizing treatment, some decreases in the wear track depths and area values were also observed. While the highest wear 

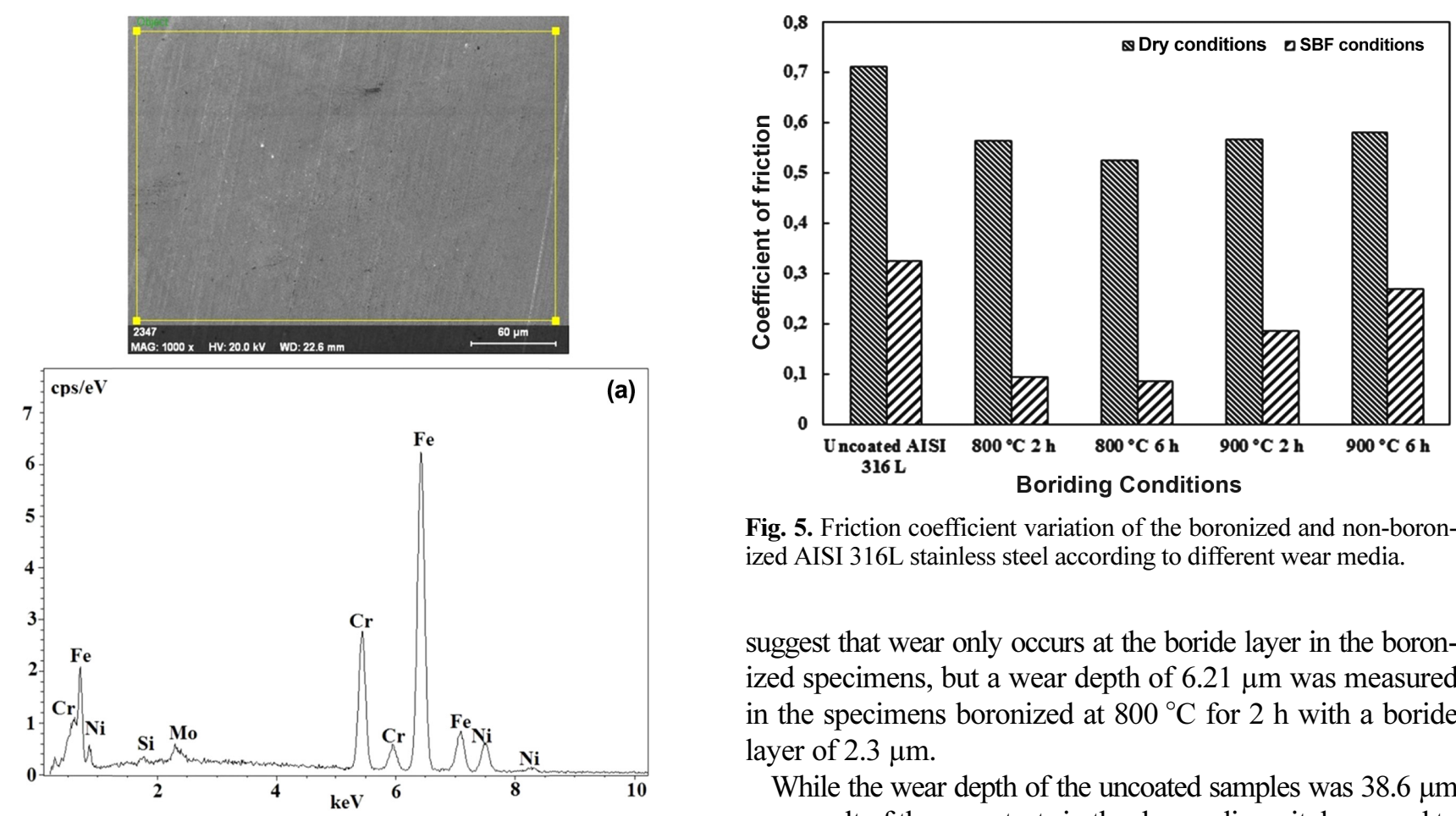

Fig. 5. Friction coefficient variation of the boronized and non-boronized AISI 316L stainless steel according to different wear media.

suggest that wear only occurs at the boride layer in the boronized specimens, but a wear depth of $6.21 \mu \mathrm{m}$ was measured in the specimens boronized at $800{ }^{\circ} \mathrm{C}$ for $2 \mathrm{~h}$ with a boride layer of $2.3 \mu \mathrm{m}$.

While the wear depth of the uncoated samples was $38.6 \mu \mathrm{m}$ as a result of the wear tests in the dry medium, it decreased to $3.19 \mu \mathrm{m}$ in the wear tests in the SBF medium. It was determined that the SBF medium reduced the wear rate (Table 4).

The wear rates obtained from the different wear regions are given in Fig. 6. The wear rate variation diagrams of the boronized AISI 316L stainless steel subjected to different wearing mediums can also be seen in Fig. 6. As a result, it was determined that the wear rates varied between $10.4 \times 10^{-6}$ $\mathrm{mm}^{3} / \mathrm{Nm}$ and $304 \times 10^{-6} \mathrm{~mm}^{3} / \mathrm{Nm}$ in the dry medium and between $2.19 \times 10^{-6} \mathrm{~mm}^{3} / \mathrm{Nm}$ and $7.81 \times 10^{-6} \mathrm{~mm}^{3} / \mathrm{Nm}$ in the SBF medium. A decrease in the wear rate with respect to the increase in the boronizing time and temperature was determined. In both mediums, the boronized sample exhibited a wear resistance much higher than the uncoated samples. As reported in the literature, the wear resistance values of the boride phases were extremely high $[26,38]$.

Both in the dry medium and the SBF medium, a decrease in the wear rates of the boronized samples was observed as the temperature of the boronizing treatment increased. While the highest rate of wear was observed in the uncoated AISI 316L stainless steel tested in the dry medium, the lowest rate of wear was observed in the specimens that were boronized at $900{ }^{\circ} \mathrm{C}$ for $6 \mathrm{~h}$ and wear tested in the SBF medium. The samples boronized at $900{ }^{\circ} \mathrm{C}$ exhibited higher wear resistance due to the increased boride layer thickness. The highest rate of wear was found in the samples that were boronized at $800^{\circ} \mathrm{C}$ for $2 \mathrm{~h}$ tested in the dry medium. It is thought that the thin boride layer was consumed rapidly and the matrix was subjected to wear action. With increases in the boronizing temperature, increases in the boride layer thicknesses and decreases in the wear rates were also observed. While a

Fig. 4. EDX analyses of the AISI 316L stainless steel surfaces $900{ }^{\circ} \mathrm{C}$ for $6 \mathrm{~h}$.

track depth occurred in the uncoated AISI 316L stainless steel that was wear tested in the dry medium, the lowest wear track depth occurred in the sample boronized at $900{ }^{\circ} \mathrm{C}$ for $6 \mathrm{~h}$, which was wear tested in the SBF medium. The results 
Table 4. Results of the wear depth and area.

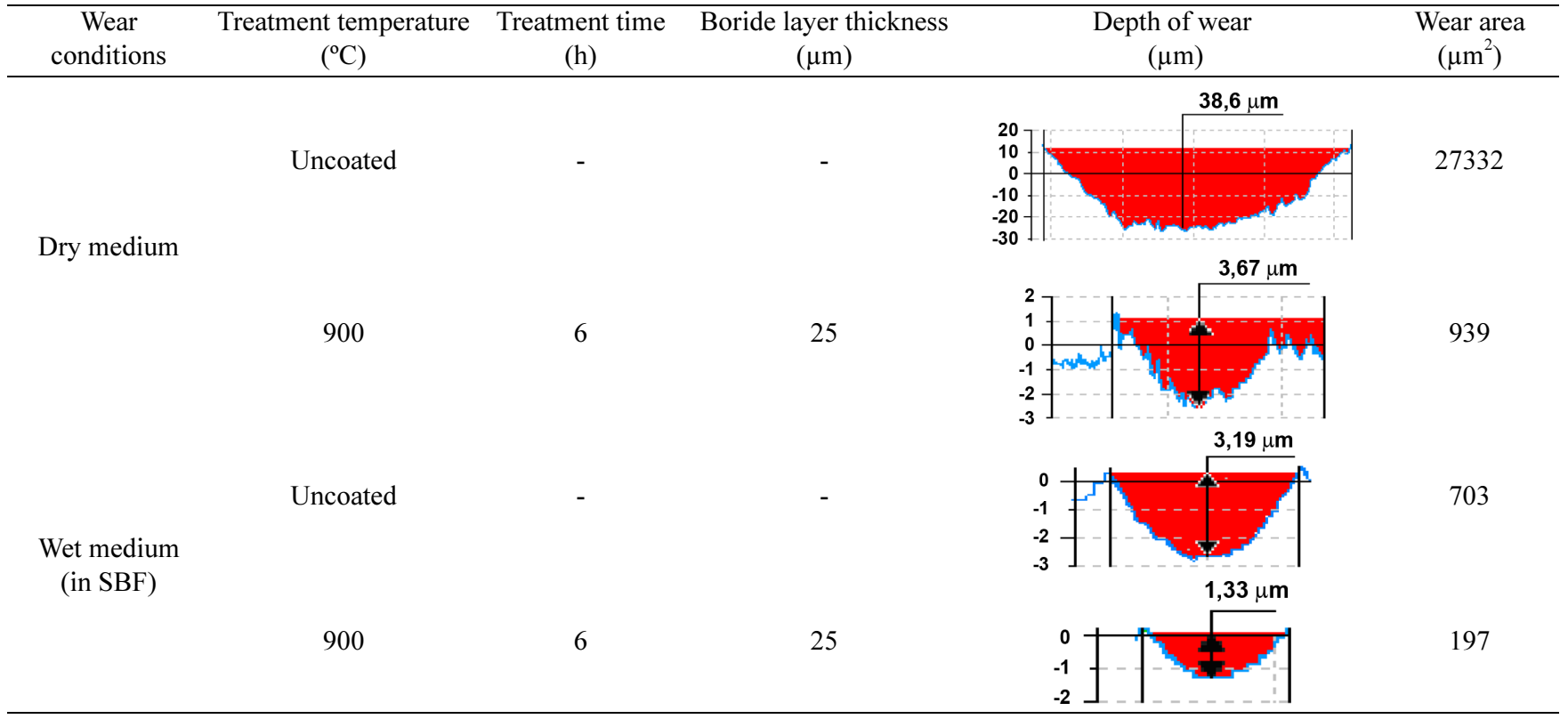

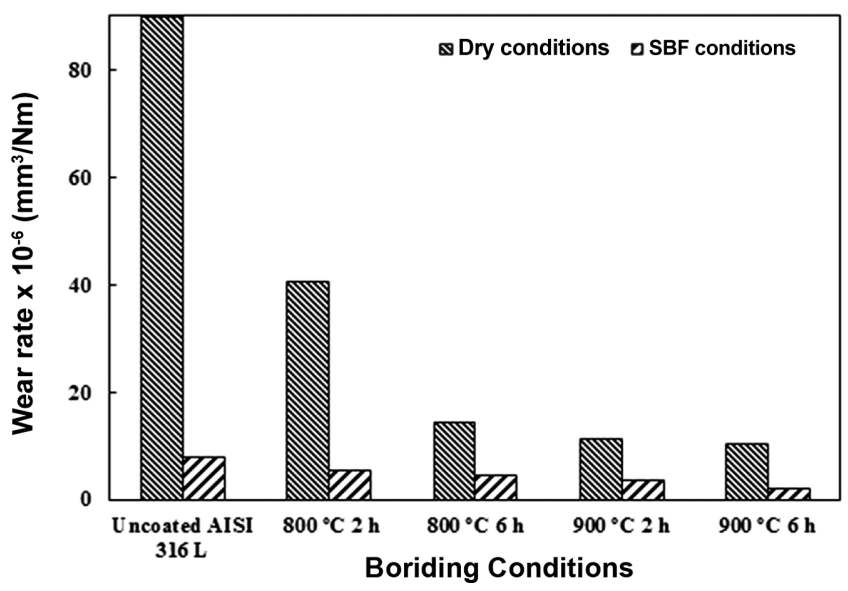

Fig. 6. Wear rate variation of the boronized and non-boronized AISI $316 \mathrm{~L}$ stainless steel according to different wear media.

higher volume of $\mathrm{Fe}_{2} \mathrm{~B}$ phase was obtained at low temperatures, it was confirmed by X-ray analysis that the $\mathrm{FeB}$ and $\mathrm{CrB}$ phases were dominant at high temperatures. The high hardness values obtained due to the $\mathrm{FeB}$ and $\mathrm{CrB}$ phases provided a high wear resistance [39-42].

When the wear tracks were examined under SEM (Fig. 7), it was observed that the adhesive wear was effective in the uncoated samples but the wear tracks in the boronized specimens indicated both abrasive and adhesive wear. In the wear tests performed in the dry medium, the wear mechanism gained abrasive characteristics due to the occurrence of deep scars that resulted from scratching. The wear tracks indicated that the surfaces were substantially oxidized; they exhibited a dominant oxidation wear behavior in the wear tests performed in the SBF medium. This finding was sup-
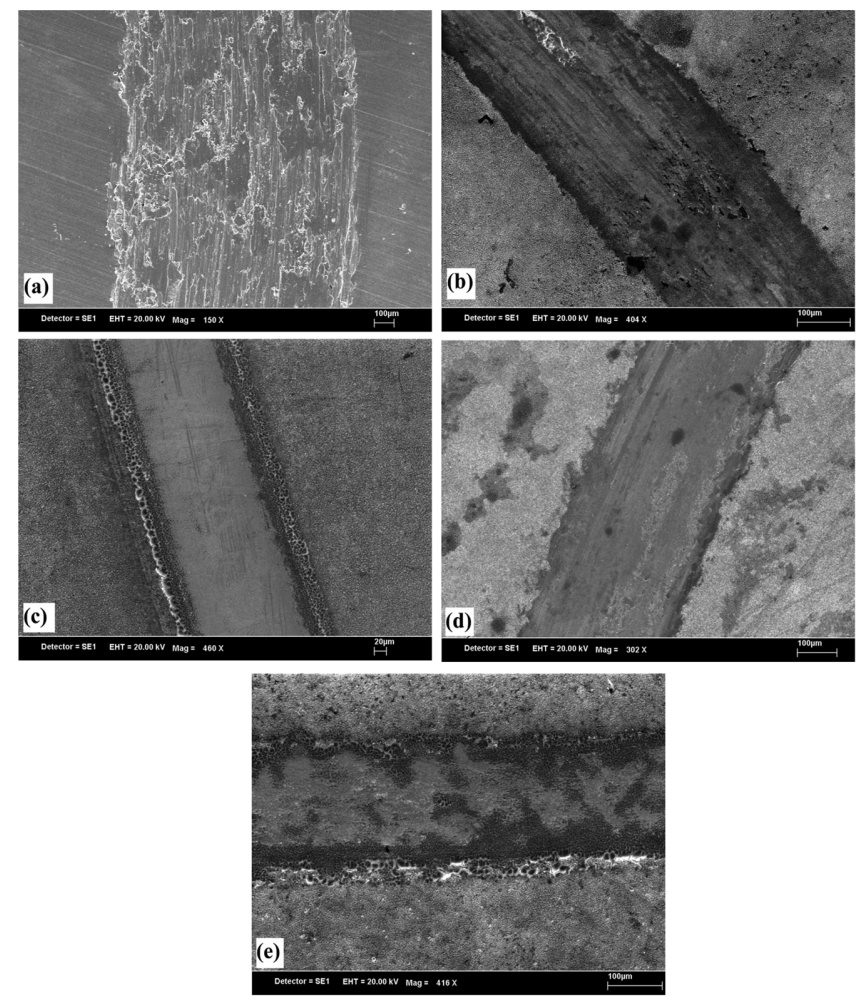

Fig. 7 SEM wear trace images of AISI 316L stainless steel: (a) nonboronized in a dry medium, (b) boronized at $800{ }^{\circ} \mathrm{C}$ for $6 \mathrm{~h}$ in a dry medium, (c) boronized at $800{ }^{\circ} \mathrm{C}$ for $6 \mathrm{~h}$ in the SBF medium, (d) boronized at $900{ }^{\circ} \mathrm{C}$ for $6 \mathrm{~h}$ in a dry medium, and (e) boronized at $900{ }^{\circ} \mathrm{C}$ for $6 \mathrm{~h}$ in the SBF medium.

ported by the EDX analyses that demonstrated that the wear debris accumulated on the edges of the wear tracks with the SBF medium. It is thought that the abrasive wear decreased 

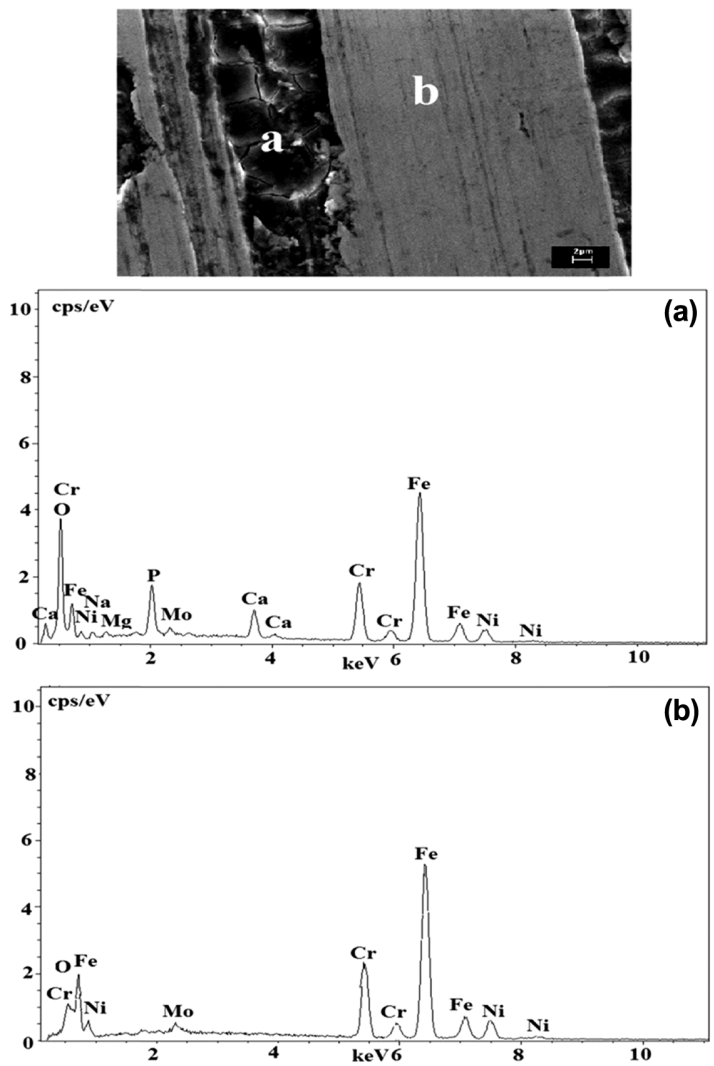

Fig. 8. EDX wear trace analysis of the non-boronized AISI 316L stainless steel in the SBF medium.
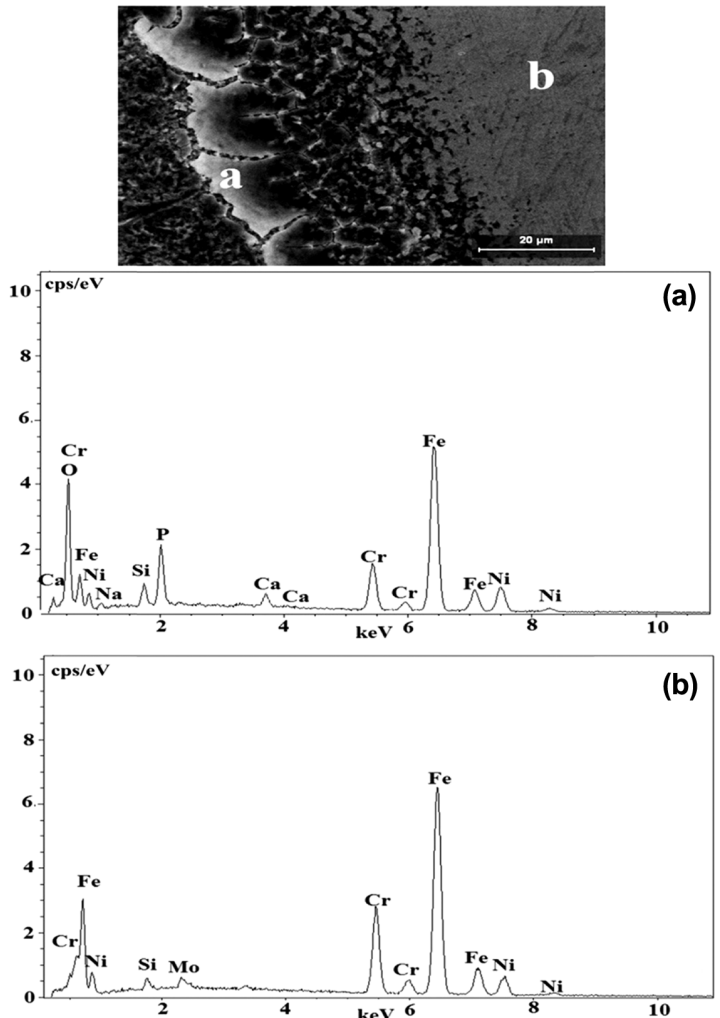

Fig. 9. EDX wear trace analysis of the AISI 316L stainless steel boronized at $800^{\circ} \mathrm{C}$ for $6 \mathrm{~h}$ in the SBF medium.
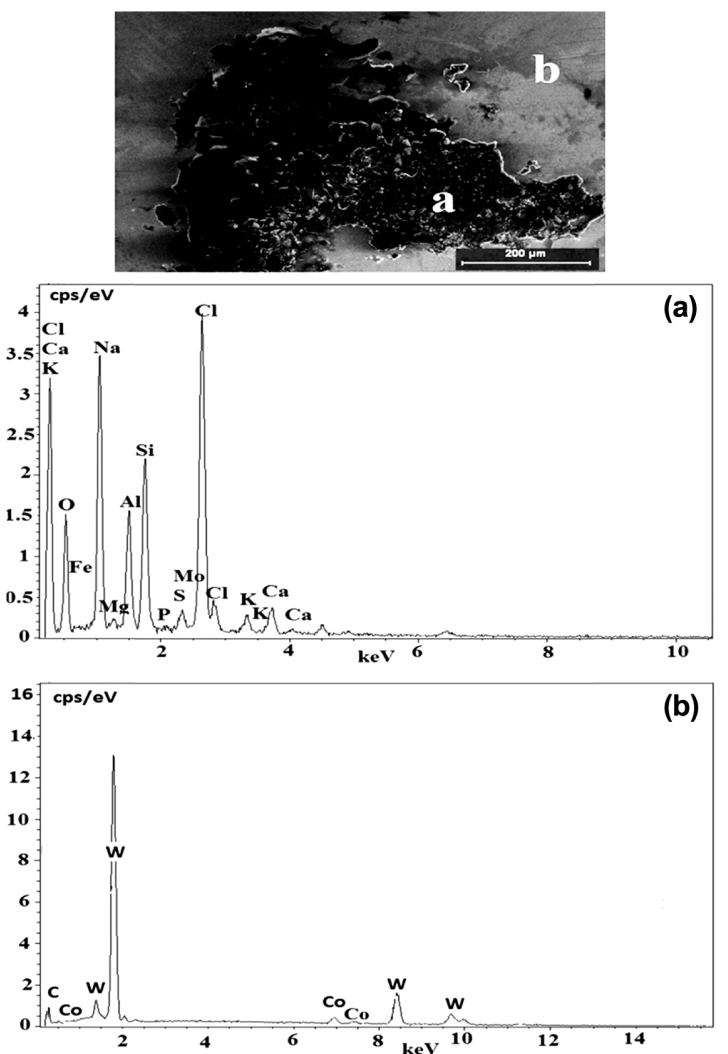

Fig. 10. EDX analysis of the WC-Co abrasive balls boronized at $800{ }^{\circ} \mathrm{C}$ for $6 \mathrm{~h}$ AISI $316 \mathrm{~L}$ stainless steel in the SBF medium.

when debris does not exist or exists in small amounts.

In Figs. 8 to 10, the EDX point analyses from both boronized and non-boronized AISI 316L stainless steels, and from points $\mathrm{A}$ and $\mathrm{B}$ on the WC-Co abrasive ball, are shown. When Fig. 8 is examined, deep wear tracks are observed in the uncoated samples as a result of the wear test performed in the SBF medium. It was determined via EDX analyses that the deep wear tracks were filled with the SBF medium, which caused cracking after solidification [36].

As seen in Fig. 9, for the samples that were boronized at $800{ }^{\circ} \mathrm{C}$ for $6 \mathrm{~h}$, the edge of the wear track had a low boride thickness due to wear in the SBF medium. It was determined through the EDX analyses that the SBF medium and boride debris accumulated on this wear track edge and the cracks occurred due to the solidification of the SBF medium. In addition, it was thought that the SBF medium covered the abrasive ball, thus reducing the wear rate in the wear tests performed in the SBF medium. As a result of the wear tests, wear on the abrasive ball could not be observed (Fig. 10).

As a result of the wear tests performed in the SBF medium, it was thought that the SBF medium formed a thin oxide layer that reduced the wear rate. This oxide layer was also determined using EDX analyses [36,43-45]. EDX point analyses were conducted on a wear track (point A) and wear 


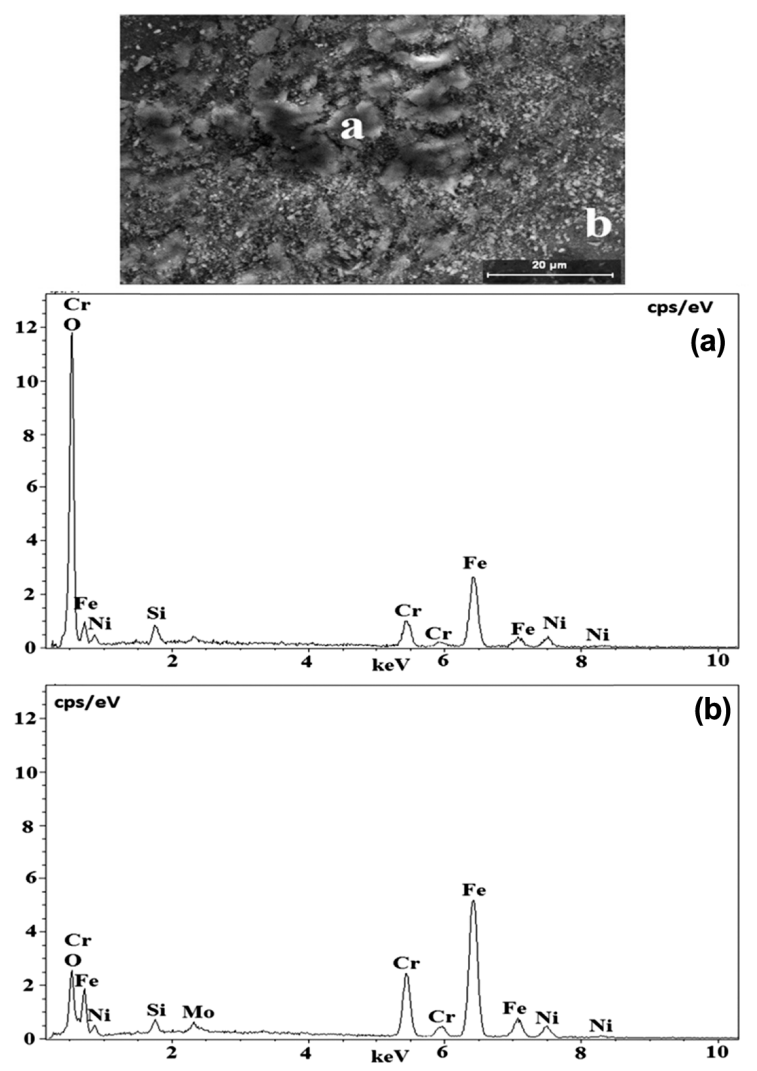

Fig. 11. EDX wear trace analysis of AISI 316L stainless steel boronized at $900{ }^{\circ} \mathrm{C}$ for $6 \mathrm{~h}$ in a dry medium.

edge (point B) of the sample that was boronized at $900{ }^{\circ} \mathrm{C}$ for $6 \mathrm{~h}$ and worn in the dry medium. According to the analyses, it is understood that while point a has a higher oxygen content, point B has a higher Fe content (Fig. 11). The SEM image suggests that the Fe-based oxide layers were formed in the wear region. The layers were fragmented towards the shifting direction and they were carried throughout the track.

\section{CONCLUSIONS}

As a result of the metallographic examinations of boronized AISI 316L stainless steel specimens, it was observed that coating matrix interface morphology has a smooth and flat structure. The thickness of the boride layer varied between $2.3 \mu \mathrm{m}$ and $25 \mu \mathrm{m}$ according to the chemical composition of the base material, boronizing time, and boronizing temperature. It was determined via $\mathrm{X}$-ray diffraction analyses that $\mathrm{FeB}, \mathrm{Fe}_{2} \mathrm{~B}, \mathrm{CrB}, \mathrm{Cr}_{2} \mathrm{~B}, \mathrm{NiB}$, and $\mathrm{Ni}_{2} \mathrm{~B}$ phases exist on the material surface as a result of the boronizing.

The matrix hardness of the AISI $316 \mathrm{~L}$ stainless steel was $334 \mathrm{HK}_{0.05}$; after boronizing, the surface hardness was measured between $1836 \mathrm{HK}_{0.05}$ and $2227 \mathrm{HK}_{0.05}$ according to the boronizing time and temperature.

In the SBF medium, the polarization current density val- ues increased after holding for $1 \mathrm{~h}$ and $168 \mathrm{~h}$ with boronizing. Although the expected improvement was not seen in the corrosion resistance of the boronized AISI 316L stainless steels, the corrosion resistance was at acceptable values.

The friction coefficient values of the boronized AISI 316L stainless steels exhibited a decrease both in the dry medium and SBF medium. With increasing boronizing temperatures and times, the wear rate decreased. In the dry medium, the wear rates of the coated specimens were 30 times lower than that of the uncoated specimens. In the SBF medium, wear rates that were approximately three times lower were obtained.

With increasing boronizing temperatures, increases in the boride layer thicknesses were observed and decreases in the wear rates were also determined. While the highest wear rate was observed in the non-boronized AISI 316L stainless steel in the dry medium, the lowest wear rate was observed in the samples that were boronized at $900{ }^{\circ} \mathrm{C}$ for $6 \mathrm{~h}$ and wear tested in the SBF medium.

Debris that resulted from the SBF medium accumulated on the wear track edges. In the SEM images of the wear tracks formed, it was observed that Fe-based oxide layers were formed and fragmented towards the shifting direction in the dry medium and were carried along the wear track. As a result, although the boronizing treatment had an acceptable negative effect on the corrosion resistance, the low surface hardness and wear performance of the AISI 316L stainless steel was improved.

\section{ACKNOWLEDGMENTS}

The authors thank the Scientific Research Project Council of Afyon Kocatepe University for their support of this project.

\section{REFERENCES}

1. L. Gil, S. Brühl, L. Jiménez, O. Leon, R. Guevara, and M. H. Staia, Surf. Coat. Tech. 201, 4424 (2006).

2. E. D. L. Heras, D. A. Egidi, P. Corengia, D. G. Santamaria, A. G. Luis, M. Brizvela, G. A. Lopez, and M. F. Martinez, Surf. Coat. Tech. 202, 2945 (2008).

3. L. Nosei, S. Farina, M. Ávalos, L. Náchez, and B. J. Gómez, Thin Solid Films 516, 1044 (2008).

4. A. F. Yetim, F. Yildiz, A. Alsaran, and A. Celik, Kovove Materials 46, 105 (2008).

5. Y. Khelfaoui, M. Kerkar, A. Bali, and F. Dalard, Surf. Coat. Tech. 200, 4523 (2006).

6. L. Chenglong, Y. Dazhi, L. Guoqiang, and Q. Min, Mater. Lett. 59, 3813(2005).

7. C. Liu, G. Lin, D. Yang, and M. Qi, Surf. Coat. Tech. 200, 4011 (2006).

8. M. Li, S. Luo, C. Zeng, J. Shen, H. Lin, and C. Cao, Corros. Sci. 46, 1369 (2004).

9. M. Azzia, M. Paquette, J. A. Szpunara, J. E. KlembergSapiehab, and L. Martinu, Wear 267, 860 (2009). 
10. M. M. Morshed, B. P. McNamara, C. D. Cameron, and M. S. J. Hashmi, Surf. Coat. Tech. 163-164, 541 (2003).

11. L. R. Jordan, A. J. Betts, K. L. Dahm, P. A. Dearnley, and G. A. Wright, Corros. Sci. 47, 1085 (2005).

12. L. Fedrizzi, S. Rossi, F. Bellei, and F. Deflorian, Wear 253, 1173 (2002).

13. A. Fossati, F. Borgioli, E. Galvanetto, and T. Bacci, Corros. Sci. 48, 1513 (2006).

14. C. N. Chang and F. S. Chen, Mater. Chem. Phys. 82, 281 (2003).

15. P. A. Dearnley and G. A. Smith, Wear 256, 491 (2004).

16. G. K. Kariofillis, G. E. Kiourtsidis, and D. N. Tsipas, Surf. Coat. Tech. 201, 19 (2006).

17. S. K. Tiwari, T. Mishra, M. K. Gunjan, A. S. Bhattacharyya, T. B. Singh, and R. Singh, Surf. Coat. Tech. 201, 7582 (2007).

18. A. K. Sinha, J. Heat Treating 4, 437 (1991).

19. İ. Özbek, S. Şen, M. İpek, C. Bindal, S. Zeytin, and A. H. Üçışık, Vacuum 73C, 643 (2004).

20. F. P. Goeuriot, J. Thevenot, and H. Driver, Thin Solid Films 78, 67 (1981).

21. E. Atık, U. Yunker, and C. Meric, Tribol. Int. 36, 155 (2003).

22. A. Pertek and M. Kulka, J. Mater. Sci. 38, 269 (2003).

23. K. S. Nam, K. H. Lee, D. Y. Lee, and Y. S. Song, Suf. Coat. Tech. 197, 51 (2005).

24. K. Genel, Vacuum 80, 451 (2006).

25. O. Allaoui, N. Bouaouadja, and G. Saindernan, Surf. Coat. Tech. 201, 3475 (2006).

26. M. Tabur, M. Izciler, F. Gulb, and I. Karacan, Wear 266, 1106 (2009).

27. C. K. N. Oliveira, L. C. Casteletti, A. Lombardi Neto, G. E. Totten, and S. C. Heck, Vacuum 84, 792 (2010).

28. C. Meriç, S. Şahin, and S. S. Yılmaz, Mater. Res. Bull. 35C, 2165 (2000).
29. İ. Özbek, B. A. Konduk, C. Bindal, and A. H. Ucisik, Vacuum 65, 521 (2002).

30. H. J. Hünger and G. True, Heat Treat. Met. 2, 31 (1994).

31. S. Taktak, J. Mater. Sci. 41, 7590 (2006).

32. S. Taktak, Mater. Design 28, 1836 (2007).

33. O. Özdemir, M. A. Omar, M. Usta, S. Zeytin, C. Bindal, and A. H. Ucisik, Vacuum 83, 175 (2009).

34. S. Sen, U. Sen, and C. Bindal, Mater. Lett. 60, 3481 (206).

35. B. Selçuk, R. İpek, and M. B. Karamış, J. Mater. Process. Tech. 141, 189 (2003).

36. R. Ribeiro, S. Ingole, M. Usta, C. Bindal, A. H. Ucisik, and H. Lianga, Vacuum 80, 1341 (2006).

37. S. Taktak, Surf. Coat. Tech. 201, 2230 (2006).

38. I. Celikyurek, B. Baksan, O. Torun, and R. Gurler, Intermetallics 14, 136 (2006).

39. S. Sen, I. Özbek, U. Sen, and C. Bindal, Surf. Coat. Tech 135, 173 (2001).

40. C. Martini, G. Palombarini, G. Poli, and D. Prandstraller, Wear 256, 608 (2004).

41. C. Meriç and S. Şahin, Science Technology of Welding \& Joining 7, 107 (2002).

42. I. Uslu, H. Comert, M. Ipek, O. Ozdemir, and C. Bindal, Mater. Design 28, 55 (2007).

43. R. Ribeiro, S. Ingole, M. Usta, C. Bindal, A. H. Ucisik, and H. Lianga, Wear 262, 1380 (2007).

44. E. Takeuchi, K. Fujii, and T. Katakırı, Wear 55, 121 (1979). 45. A. Erdemir, J. Soc. Tri. \& Lub. Eng. 47, 168 (1991).

46. A. Parsapour, S. N. Khorasani, and M. H. Fathi, J. Mater. Sci. Technol. 28, 125 (2012).

47. B. Weiss and R. Stickler, Metall. Trans. 3, 851 (1972).

48. G. Y. Lai, High-Temperature Corrosion and Materials Applications, 1st ed., pp.10-50, ASM International, United States (2007). 